\title{
I6S rRNA sequence-based analysis of bacterial communities associated with the selected mosses of Mount Abu (Rajasthan), India
}

\begin{abstract}
The phyllosphere of bryophytes offers an excellent habitat to various other microorganism to flourish. This fascinating association among bryophytes and soil borne microorganisms have significant ecological and physiological roles including $\mathrm{N}_{2}$ fixation, soil-enrichment, promotion of protonemal growth and bud formation. However, our understanding regarding the ecological aspects of this association is still little known, and if consider at molecular level it becomes rare. So far, only sporadic works have been done, and for better understanding related to this ignored concern and there is a necessity to address this. Hence, the present study was done to elucidate the structure and biological roles of bacterial diversity coupled with the bryophytes and their dynamics on selected taxa in different ecosystems. Phylogenetic analysis of bacterial community associated with selected mosses was carried out. The work is primarily based on the $16 \mathrm{~S}$ rRNA sequencing approach. Moss taxa viz., Anoectangium clarum Mitt., Hyophila involuta (Hook.) A. Jaeger and Atrichhum undulatum (Hedw.) P. Beauv., were collected from different locations of Mount Abu, Rajasthan. The outcome of the study estimated that the microbial communities associated with these mosses belong mainly to phylum proteobacteria and fermicutes with the dominance of $\gamma$-proteobacteria. This genus found frequently associated to the species of different habitat, soil, near water channel and the rocks are Pseudomonas, Aeromonas, Routella and Halobascillus. This study provides the groundwork information about the exceptional relationship of these bacteria with mosses and would be helpful for the future research in this direction.
\end{abstract}

Volume 3 Issue 5 - 2019

\author{
Saumya Pandey, Shivangi Pandey, Afroz Alam \\ Department of Bioscience and Biotechnology, Banasthali \\ Vidyapith University, India
}

Correspondence: Afroz Alam, Department of Bioscience and Biotechnology, Banasthali Vidyapith University, Tonk,304022, Rajasthan, India, Email afrozalamsafvi@gmail.com

Received: August 13,2019 | Published: October 18, 2019

Keywords: bacterial community, bryophytes, endophytes, mosses

\begin{abstract}
Abbreviations: FISH, fluorescent in situ hybridization; CLSM, confocal laser scanning microscopy; SSCP, single-strand conformation polymorphism
\end{abstract}

\section{Introduction}

The plant-microbes association is considered indispensable for the growth and development of plants. ${ }^{1}$ Bacteria associated with the plants are mainly endophytes and barely epiphytes that help to improve the plant growth by promoting soil enrichment, ${ }^{2}$ degradation of organic pollutants, ${ }^{3-5}$ plant hormones and vitamin synthesis, $\mathrm{N}_{2}$ fixation, suppression of the development of bacterial and fungal diseases, ${ }^{6-7}$ and can also enhance the host capability to adapt under extreme environment. ${ }^{8}$ Bacterial associations are present in nearly all the plant species that exists on earth. ${ }^{9}$ Despite this prevalent dependence, astoundingly, the majority of research focused only on the higher plants-bacterial association and the structure or diversity of bacteria associated with lower plants such as bryophytes has been neglected. ${ }^{10}$ Bryophytes are the primitive and simplest non-vascular plants/first land plants that are composed of mosses, liverworts and hornworts, and are considered to be the ancestors of pteridophytes and all other tracheophytes. ${ }^{11-12}$ Bryophytes consists of nearly 25,000 species worldwide ${ }^{13}$ distributed in diverse ecological condition ranging from polar and alpine regions to tropic ${ }^{14}$ and also played an important role in biota formation along with the settlement of land by plants. ${ }^{15}$ Bryophytes have been suggested as excellent candidates for evaluating the ecological and evolutionary impacts of the habitat fragmentation due to their global ubiquity, fast-growing nature, substrate specificity, and dominant haploid gametophytes. ${ }^{14}$ They have also been adopted and employed as model organisms and exploited for different kinds of biotechnological applications. ${ }^{16-17}$ Bryophytes play imperative roles in nutrient cycling and can act as bio-indicators of air pollutants or heavy metals, making them crucial to the environmental health of many ecosystems. ${ }^{18}$

Nowadays, bryophytes are gaining great attention from several researchers because of its distinctive properties and availability of biotechnological tools to exploit it in different aspects useful for better understanding of evolution and ecology. A number of studies showed that bryophytes-microorganism association is prevalent in the environment, ${ }^{10,19-21}$ but till now the nature and bio-functional diversity of these microbial communities inhabiting in/on the bryophytes remains unknown. ${ }^{20}$ This draws the attention of several researchers to study the bryophytes-associated microorganisms and their relationship with bryophytes and its habitat. Currently the detailed understanding of microbial community structure and its associated biological role are available for only few genera of bryophytes. ${ }^{10,22}$ The peat moss, Sphagnum is the most exploited genus among bryophytes to study the abundance, structure and function of the endo/ectophytic bacteria associated with plant., ${ }^{7,29}$ Apart from this, other genera such as Hygroamblystegium spp., Entodon spp., Grimmiia spp., ${ }^{21}$ Brachythecium spp., Haplocladium spp., Bryum spp., ${ }^{20}$ Funaria spp., ${ }^{10}$ Tortula $^{19}$ has been studied for microbial association. Several studies provide insights into the correlation between the ecosystem 
or geographical region and abundance of microbial community. ${ }^{20,21}$ Several methods has been used to study the bryophytes-microbial association such as scanning electron/fluorescence microscopy, ${ }^{10}$ Fluorescent in situ Hybridization (FISH) and Confocal Laser Scanning Microscopy (CLSM), ${ }^{7}$ Single-strand conformation polymorphism $(\mathrm{SSCP}),{ }^{19}$ 16S rRNA and 16S rDNA sequencing, ${ }^{21}$ DGGE-PCR sequencing ${ }^{25}$ and Illumina sequencing. ${ }^{26}$

Microbial strains such Burkholderia, Serratia, Hafnia, Pantoea, Methanobacteria and Methylobacteria were found abundantly as endophytes, epiphytes or both, in some mosses. ${ }^{19,22}$ Some of these microorganisms possess unique characteristic property such as $\mathrm{N}_{2}$ fixation, mineral phosphate solublization, ACC deaminase activity and PGR (Plant Growth Regulators) production, which make them valuable tools for agricultural biotechnology. ${ }^{27}$ In addition, many of isolated moss-associated bacteria have antagonistic property against several phytopathogenic fungi. ${ }^{28}$ In this study, the diversity and community structure of three bryophyte species collected from three different locations of Mount Abu were investigated and compared based on culture-independent approach of 16S rRNA sequencing method of Tian. ${ }^{21}$ As the study is based on only a few sequences so it provides only the groundwork scenario of microbial community diversity and the relationship between the ecosystem and bryophyte species in association with bacterial community. For comprehensive and significant evaluation of the associated microbial community of the Mount Abu region, diverse ecosystem and associated mosses should be taken into account for upcoming study.

\section{Materials and methods}

\section{Sampling sites and surface treatment}

To evaluate the bacterial community structure of the bryophytes three mosses, Anoectangium clarum, Hyophila involuta and Atrichum undulatum were collected during the spring season of 2014 from Mount Abu, which is located in the western part of India with longitude and latitude $72.7083^{\circ} \mathrm{E} 24.5925^{\circ} \mathrm{N}$ respectively. Three sites were selected for sampling; (a) surface of rock, (b) moist soil, (c) near water channels (Table 1). The collected samples were submitted and identified as taxonomically distinct species at Banasthali University Herbarium, Rajasthan and used for further analysis. The samples were washed with running tap water to remove attached soil. Then, the samples were immersed in $70 \%$ ethanol for $3 \mathrm{~min}$ and followed by washing five times with sterile distilled water.

Table I The three mosses collected from different locations of Mount Abu, Rajasthan

\begin{tabular}{llll}
\hline S.No & Name of Samples & $\begin{array}{l}\text { Herbarium } \\
\text { number }\end{array}$ & $\begin{array}{l}\text { Source of } \\
\text { Samples }\end{array}$ \\
\hline 1 & $\begin{array}{l}\text { Anoectangium clarum Mitt. } \\
\text { (Pottiaceae) }\end{array}$ & BURI786030I & Moist Soil \\
2 & $\begin{array}{l}\text { Hyophila involuta (Hook.) Jaeg. } \\
\text { (Pottiaceae) }\end{array}$ & BURI78603I8 & $\begin{array}{l}\text { Near water } \\
\text { Channel }\end{array}$ \\
3 & $\begin{array}{l}\text { Atrichum undulatum (Hedw.) P. } \\
\text { Beauv. (Polytrichaceae) }\end{array}$ & BURI786 & $\begin{array}{l}\text { Shaded } \\
\text { rocky ledges }\end{array}$ \\
\hline
\end{tabular}

\section{Total DNA extraction and PCR amplification}

The genomic DNA of bacterial cell consortia was extracted from $1 \mathrm{gm}$ of surface treated moss using Fast DNA spin kit for soil (MPBIO) according to manufacturer's instruction. The eluted DNA was used diluted and used for the PCR reaction.

\section{Amplification of bacterial I6S rRNA genes and Phylogenetic analysis}

The 16S rRNA gene fragments were amplified with the universal bacterial primer sets 799F (50-AACAGGATTAGATACCCTTG-30 $)^{29}$ and 1492R (50-TACGGYTACCTTGTTACGACT-30). ${ }^{30}$ The PCR was performed using a $15 \mathrm{ul}$ mixture containing $25 \mathrm{ng} / \mu 1$ of DNA $2.5 \mathrm{mM}$ each of dNTPs, $1.5 \mathrm{mM} \mathrm{MgCl}_{2}, 10 \mu \mathrm{M}$ of forward and reverse primers and, $0.2 \mathrm{U}$ of Taq DNA polymerase (Genei). The amplifications were performed using a thermal cycler (Primus 96) with subsequent plan, i.e. initial denaturation at $94^{\circ} \mathrm{C}$ for $5 \mathrm{~min} ; 35$ cycles of $1 \mathrm{~min}$ at $94^{\circ} \mathrm{C}$, $1 \mathrm{~min}$ at annealing temperature $53^{\circ} \mathrm{C}$ and $2 \mathrm{~min}$ at $72^{\circ} \mathrm{C}$; and a final elongation step of $5 \mathrm{~min}$ at $72^{\circ} \mathrm{C}$. PCR products were separated by the electrophoresis technique using a $1 \%$ agarose gel. The six bands of approximately $250 \mathrm{bp}$ in size were excised and purified by the Hiyield Gel/PCR DNA Mini Kit as described by the manufacturer (Figure 1). The sequencing of the purified eluted product was performed by Applied Biosystems (India). Similarity searches in GenBank were performed using BLAST. ${ }^{31}$ The DNA sequences were analyzed for the closest neighbours among sequenced 16 rDNA regions of different bands using PAUP version 4 (Figure 2). ${ }^{32}$

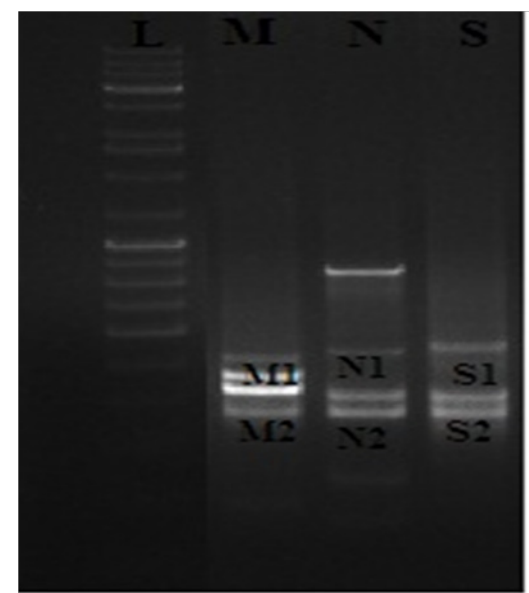

Figure I I6S rRNA PCR gel of bryophytes associated bacteria of three different locations of Mount Abu, Rajasthan. Sample loaded on I.5\% agarose gel lanes are: L, Medium range DNA ladder and lane $\mathrm{M}, \mathrm{N}$ and $\mathrm{S}$ indicate samples isolated from moist soil, near water channel and rocks, respectively.

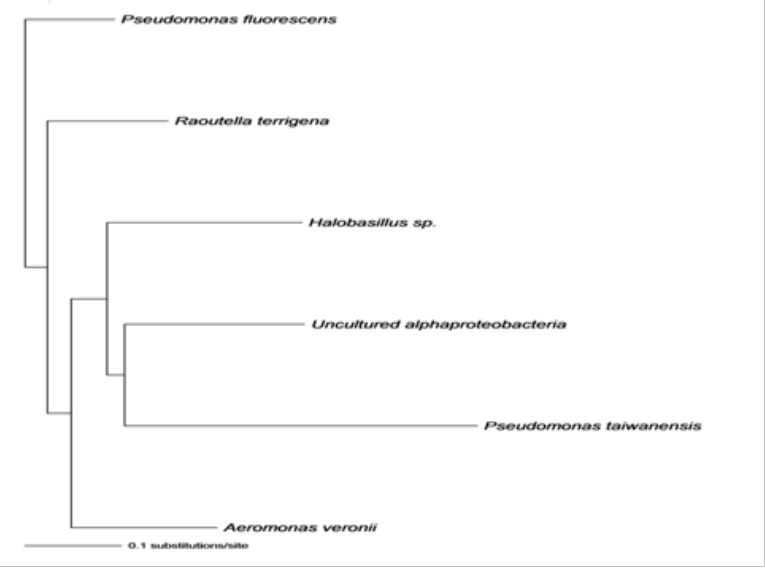

Figure 2 Neighbor-joining Phylogenetic analysis constructed based on comparative analysis of 6 individual amplified I6S rRNA gene of the bacterial community structure associated with three bryophyte species using multiple alignments CLUSTALW. 


\section{Result and discussion}

16S rRNA sequencing approach is most widely used method to study biological community structure associated with bryophytes species. ${ }^{21}$ In the present study, five out of six excised and sequenced bands from agarose gel from three bryophyte species were assigned taxonomic phyla (Figure 1). The phylogenetic analysis showed the presence of two phyla, proteobacteria and fermicutes with predomination of $\gamma$-Proteobacteria. The result showed that the bacterial communities inhabiting bryophytes species collected from soil and near water channel consists mainly of proteobacteria while those from rocks has both proteobacteria and fermicutes (Table 2). This study is in agreement with earlier reports that the shift in ecosystem shift brings the change in predominance of bacterial communities inhabiting the associated hosts. ${ }^{20,33}$

Table 2 Phylogenetic analysis of the bacterial community structure of three bryophyte species isolated from three different locations of Mount Abu, Rajasthan

\begin{tabular}{|c|c|c|c|c|c|c|}
\hline \multirow[t]{2}{*}{ Closest BLAST matches } & \multirow[t]{2}{*}{ Band } & \multirow{2}{*}{$\begin{array}{l}\text { Location of } \\
\text { Samples }\end{array}$} & \multirow{2}{*}{$\begin{array}{l}\text { Bryophyte } \\
\text { species }\end{array}$} & \multicolumn{3}{|c|}{ Closest matches characterization } \\
\hline & & & & Acession No. & $\begin{array}{l}\% \\
\text { identity }\end{array}$ & Taxonomic group \\
\hline $\begin{array}{l}\text { Pseudomonas taiwanensis strain SJPS } \\
\text { KUD54 }\end{array}$ & MI & Moist soil & $\begin{array}{l}\text { Anoectangium } \\
\text { clarum }\end{array}$ & KX094893.I & 79 & $\gamma$-proteobacteria \\
\hline Aeromonas veronii strain Philippines-AnI I & M2 & Moist soil & $\begin{array}{l}\text { Anoectangium } \\
\text { clarum }\end{array}$ & EF446897.I & 78 & $\gamma$-proteobacteria \\
\hline Pseudomonas fluorescens strain DI9 & $\mathrm{NI}$ & $\begin{array}{l}\text { Near water } \\
\text { channel }\end{array}$ & Hyophila involuta & KT767767.I & 93 & $\gamma$-proteobacteria \\
\hline $\begin{array}{l}\text { Uncultured } \alpha \text {-proteobacterium clone } \\
\text { RLBp5566 }\end{array}$ & N2 & $\begin{array}{l}\text { Near water } \\
\text { channel }\end{array}$ & Hyophila involuta & KC449320.I & 86 & A-proteobacteria \\
\hline Routella terrigena strain $35 \mathrm{CL}$ & SI & $\begin{array}{l}\text { Shaded rocky } \\
\text { ledges }\end{array}$ & $\begin{array}{l}\text { Atrichum } \\
\text { undulatum }\end{array}$ & $K \times 2|4| 06.1$ & 82 & $\gamma$-proteobacteria \\
\hline Halobascillus sp. HPB32 & S2 & $\begin{array}{l}\text { Shaded rocky } \\
\text { ledges }\end{array}$ & $\begin{array}{l}\text { Atrichum } \\
\text { undulatum }\end{array}$ & EFI50752.I & 100 & Fermicutes \\
\hline
\end{tabular}

Bacterial species identified in all geographical regions belong to three phylogenetical group $\alpha$-proteobacteria, $\gamma$-proteobacteria and fermicutes. The $\gamma$-proteobacteria genera such as Pseudomonas and Aeromonas were found associated with bryophyte species of soil habitat (Anoectangium clarum). And also the bryophytes species (Hyophila involuta) collected from water channel were found associated with $\gamma$-proteobacteria i.e. Pseudomonas and uncultutured $\alpha$-proteobacteria. In contrast, bryophyte species (Atrichum undulatum) collected from rock habitat contains both $\gamma$-proteobacteria and fermicutes genera, Pseudomonas and Halobacillus respectively. The genus Pseudomonas was found associated with bryophyte species of both soil and rock habitat. This result showed that the bacteria community structures are different at only species level irrespective of the habitat of bryophyte species. Bragina et al., ${ }^{22}$ reported that the bacterial community structures are highly specific to their masses. However, the study involves only a few sequences due to lack of resources and contamination so the evaluation of dependency of bacterial community structure on the specific ecosystem required further investigation. This study is only preliminary approach to understand the microbial community structure and its relation with bryophytes grown in different habitat of Mount Abu.

The bacteria assigned of this report are well known as plantassociated bacteria for their impact on plant capability in diverse ways. The bacterial association may promote plant growth and health via production of phytohormones (Aeromonas \& Halobascillus) and $\mathrm{N}_{2}$ fixation (Pseudomonas \& Routella) and antagonistic property. Earlier, Opelt et al., ${ }^{23}$ reported that genus Pseudomonas has very efficient antagonistic property. ${ }^{34,35}$ According to the study, the productions of active substances by moss-associated bacteria are approximately two folds are higher than plant-associated bacteria. ${ }^{19}$ The microbial communities residing in mosses are not only beneficial for growth and health of plants but also for biotechnological applications. Thus, the knowledge of bacterial community structure and its relationship with habitat and bryophyte species as well as the benefits of associated bacteria to plant are essential to evolve strategies for their exploitation.

\section{Conclusion}

We report the bacterial community structure of three mosses collected from three different habitats of Mount Abu. The data indicate the presence of two phyla proteobacteria and fermicutes associated with mosses. However, due to inadequate resources and contamination in samples the only the few microbial species and their distribution in different habitat were studied. So this study is preliminary attempt to understand the microbial community structure of mosses from different habitat of Mount Abu. Further study can be done to study other associated microbial community and its biological role and also its specificity is host specific or habitat specific and the reason for fluctuation of diversity in different habitats.

\section{Acknowledgments}

The authors are grateful to Professor Aditya Shastri, Vice Chancellor, Banasthali Vidyapith, Rajasthan for his encouragement and support.

\section{Conflicts of interest}

The author declares there is no conflict of interest.

\section{References}

1. Hallmann J, Quadt Hallmann A, Mahaffee WF, et al. Bacterial endophytes in agricultural crops. Canadian Journal of Microbiology. 1997;43(10):895914.

2. Tilak KV, Ranganayaki N, Pal KK, et al. Diversity of plant growth and soil health supporting bacteria. Current science. 2005;89(1):136-150.

3. Morgan JA, Bending GD, White PJ. Biological costs and benefits to plant- 
microbe interactions in the rhizosphere. Journal of experimental botany. 2005;56(417):1729-1739.

4. Mastretta C, Barac T, Vangronsveld J, et al. Endophytic bacteria and their potential application to improve the phytoremediation of contaminated environments. Biotechnology and genetic engineering reviews. 2006;23(1):175-188.

5. Afzal M, Khan QM, Sessitsch A. Endophytic bacteria: prospects and applications for the phytoremediation of organic pollutants. Chemosphere. 2014; 117:232-242.

6. Strobel G, Daisy B, Castillo U, et al. Natural products from endophytic microorganisms. J Nat Prod. 2004;67(2):257-268.

7. Shcherbakov AV, Bragina AV, Kuzmina EY, et al. Endophytic bacteria of Sphagnum mosses as promising objects of agricultural microbiology. Microbiology. 2013;82(3):306-315.

8. Raymond JA. Dependence on epiphytic bacteria for freezing protection in an Antarctic moss, Bryum argenteum. Environmental Microbiology Rep. 2016;8(1):14-19.

9. Brock TC, Bregman R. Periodicity in growth, productivity, nutrient content and decomposition of Sphagnum recurvum var. mucronatum in a fen woodland. Oecologia. 1989;80(1):44-52.

10. Hornschuh M, Grotha R, Kutschera U. Epiphytic bacteria associated with the bryophyte Funaria hygrometrica: effects of Methylobacterium strains on protonema development. Plant Biology. 2002;4(6):682-687.

11. Edwards D, Duckett JG, Richardson JB. Hepatic characters in the earlies land plants. Nature. 1995;374(6523):635-636.

12. Kenrick P, Crane PR. The origin and early evolution of plants on land Nature. 1997;389(6646):33-39.

13. Buck WK, Goffinet B. Morphology and classification of mosses. In: Shaw AJ, Goffinet B. editors. Bryophyte biology. Cambridge: Cambridge University Press. 2000.

14. Pharo EJ, Zartman CE. Bryophytes in a changing landscape: the hierarchica effects of habitat fragmentation on ecological and evolutionary processes. Biological conservation. 2007;135(3):315-325.

15. Cox CJ, Goffinet B, Wickett NJ, et al. Moss diversity: a molecular phylogenetic analysis of genera. Phytotaxa. 2014;9(1):175-195.

16. Oliver MJ, Velten J, Wood AJ. Bryophytes as experimental models for the study of environmental stress tolerance: Tortula ruralis and desiccationtolerance in mosses. Plant Ecology. 2000;151(1):73-84.

17. Decker EL, Gorr G, Reski R. Moss-an innovative tool for protein production. BIOforum Europe. 2003;2:96-97.

18. Ye J, Hao Z, Yu D, et al. Research advances in bryophyte ecological function. Ying yong sheng tai xue bao. 2004;15(10):1939-1942.

19. Opelt K, Berg G. Diversity and antagonistic potential of bacteria associated with bryophytes from nutrient-poor habitats of the Baltic Sea Coast. Appl Environ Microbiol. 2004;70(11):6569-6579.

20. Koua FH, Kimbara K, Tani A. Bacterial-biota dynamics of eight bryophyte species from different ecosystems. Saudi journal of biological sciences. 2015;22(2):204-210.
21. Tian Y, Li YH. Comparative analysis of bacteria associated with different mosses by $16 \mathrm{~S}$ rRNA and $16 \mathrm{~S}$ rDNA sequencing. $J$ Basic Microbiol. 2017;57(1):57-67.

22. Bragina A, Berg $\mathrm{C}$, Müller $\mathrm{H}$, et al. Insights into functional bacterial diversity and its effects on Alpine bog ecosystem functioning. Sci Rep. 2013;3:1955.

23. Opelt K, Berg C, Berg G. The bryophyte genus Sphagnum is a reservoir for powerful and extraordinary antagonists and potentially facultative human pathogens. FEMS microbiology ecology. 2007;61(1):38-53.

24. Shcherbakov AV, Kuzmina EY, Lapshina ED, et al. Taxonomic diversity of bacterial populations inhabiting gametophytes of Sphagnum mosses from different geographic regions of Russia. Agronomy Research. 2015;13(1):192-201.

25. Muyzer G, De Waal EC, Uitterlinden AG. Profiling of complex microbial populations by denaturing gradient gel electrophoresis analysis of polymerase chain reaction-amplified genes coding for $16 \mathrm{~S}$ rRNA. Applied and Environmental Microbiology. 1993;59(3):695-700.

26. Tang JY, Ma J, Li XD, et al. Illumina sequencing-based community analysis of bacteria associated with different bryophytes collected from Tibet, China. BMC microbiology. 2016;16(1):276.

27. Tani A, Akita M, Murase H, et al. Culturable bacteria in hydroponic cultures of moss Racomitrium japonicum and their potential as biofertilizers for moss production. J Biosci Bioeng. 2011;112(1):32-39.

28. Opelt K, Chobot V, Hadacek F, et al. Investigations of the structure and function of bacterial communities associated with Sphagnum mosses. Environ Microbiol. 2007;9(11):2795-2809.

29. Chelius MK, Triplett EW. The Diversity of Archaea and Bacteria in Association with the Roots of Zea mays L. Microb Ecol. 2001;41(3)252263.

30. Lane DJ. 16S/23S rRNA sequencing, In: Stackerbrandt E, Goodfellow M. editors. Nucleic Acid Techniques in Bacterial Systematics. New York: Wiley New York. 1991

31. Altschul SF, Madden TL, Schäffer AA, et al. Gapped BLAST and PSIBLAST: a new generation of protein database search programs. Nucleic acids research. 1997;25(17):3389-3402.

32. Swofford DL. PAUP, Phylogenetic analysis using parisomy (and other methods). 2001.

33. Pitta DW, Pinchak WE, Dowd SE, et al. Rumen bacterial diversity dynamics associated with changing from bermudagrass hay to grazed winter wheat diets. Microbial ecology. 2010;59(3):511-522.

34. Kurtz JC, Savka MA, Brown LA, et al. Production of plant growth promoting substances in bacterial isolates from the sea grass rhizosphere. (Poster). Annual Meeting of the American Society for Microbiology. Chicago, IL. 1999

35. Orhan F. Alleviation of salt stress by halotolerant and halophilic plant growth-promoting bacteria in wheat (Triticum aestivum). Braz J Microbiol. 2016;47(3):621-627. 